\title{
Differential responses to forest edges among populations of Oophaga pumilio (Anura: Dendrobatidae) from Panama
}

\author{
J. P. Lawrence ${ }^{1,2}$ \\ ${ }^{1}$ Department of Fisheries and Wildlife, Michigan State University. East Lansing, MI 48824, USA. \\ ${ }^{2}$ Current address: Department of Biology, University of Mississippi. Mississippi 38677, USA. E-mail: JPLarry@gmail.com.
}

\begin{abstract}
Differential responses to forest edges among populations of Oophaga pumilio (Anura: Dendrobatidae) from Panama. As habitat fragmentation increasingly becomes a prevalent feature in tropical systems, investigating how such novel features affect the distribution of species is of vital importance for understanding species' ecology and conservation concerns. Species that show interpopulation variation in features that may affect their ecology (i.e., coloration) should be of high priority for elucidating the effects fragmentation may have. It is possible that these features unique to certain populations could promote or constrain the population's ability to adapt to change. I investigated nine populations of the Strawberry Poison Frog (Oophaga pumilio) throughout the Bocas del Toro archipelago in Panama. By running transects from forest edge into interior forest, I assessed both population density and individual distance from forest edge for each population. One population was significantly denser than six of the other eight populations. Three populations showed increased numbers farther from forest edges while six populations showed no variation. This research highlights how reactions to habitat fragmentation may be population specific, possibly linked to physical traits of individuals within the population. This research suggests that high interpopulation variation should be taken into account when examining species' reactions to environmental perturbations.
\end{abstract}

Keywords: edge effects, habitat fragmentation, population density, Strawberry Poison Frog, transects.

\section{Resumo}

Respostas diferenciais às bordas de floresta entre populações de Oophaga pumilio (Anura: Dendrobatidae) do Panamá. A medida que a fragmentação torna-se uma característica prevalecente nos sistemas tropicaisl, investigar como essas novas características afetam a distribuição das espécies é de vital importância para entender a ecologia e a conservação das espécies. Espécies que apresentam variação interpopulacional em caraterísticas que podem afetar sua ecologia (por

Received 09 May 2018

Accepted 23 October 2018

Distributed December 2018 
exemplo, coloração) deveriam ter alta prioridade para elucidar os efeitos da fragmentação. É possível que essas características exclusivas de certas populações possam promover ou impor restrições à capacidade de a população adaptar-se ou transformar-se. Investiguei nove populações do dendrobatídeo Oophaga pumilio ao longo do Arquipélago de Bocas del Toro, no Panamá. Percorrendo transeptos da borda para o interior da floresta, avaliei, para cada população, a densidade e a distância dos indivíduos desde a borda. Uma das populações mostrou densidade significativamente maior que seis das outras oito populações. Três populações mostraram maior número de indivíduos a maiores distâncias da borda, enquanto seis populações não mostraram variação. Esta pesquisa ilustra como as reações à fragmentação do hábitat podem ser específicas de populações, possivelmente em associação com características físicas dos indivíduos que as compõem. Os resultados sugerem que altas variações interpopulacionais deveriam ser levadas em conta no exame das reações das espécies às perturbações ambientais.

Palavras-chave: densidade populacional, efeitos de borda, fragmentação do hábitat, transeptos.

\section{Introduction}

As awareness of the effects of habitat destruction has become more widespread, researchers have drawn attention to more nuanced ecological phenomena surrounding habitat destruction including the effects of habitat edges on population and community function (Andren and Angelstam 1988, Malcolm 1994, Fagan et al. 1999). Researchers have relatively recently hypothesized that habitat fragmentation is as important as outright habitat destruction in species declines (Goosem 2007). While there are many reasons for this, edge effects (e.g., new species invading now suitable habitat or existing species ranges being contracted within habitat fragments due to negative interactions at habitat edges) are an important component for understanding species distributions and community processes throughout a landscape (Collingham and Huntley 2000, Devictor et al. 2008, Ries and Sisk 2010).

Until relatively recently, many researchers considered habitat edges to be an ecological peculiarity for understanding community function across landscapes. Such features were not considered to have major impacts on species dynamics. Research has often been conducted on homogeneous landscapes, ignoring patchy habitats that complicate community patterns and delimitation, though this is not realistic representation of most natural systems. Edges have since been shown to have impacts on a variety of ecological processes including species interactions and limitations of dispersal (Collingham and Huntley 2000, Devictor et al. 2008). There is little debate now that habitat edges are important in determining community structure and function, and consequently has become a focus of those researching community changes due to human-mediated habitat fragmentation. A broad array of research has been conducted on the effects of habitat edges on animal fauna from birds to mammals (Herkert 1994, Eizirik et al. 2001, Crooks 2002, Kinnaird et al. 2003), but not all animal groups are well represented in the literature.

Unlike the effects of edges on large vertebrate populations (Eizirik et al. 2001, Crooks 2002, Kinnaird et al. 2003), the effects of edges on herpetofauna are poorly known, with a large portion of the literature focusing on temperate zone communities (Knutson et al. 1999, Marsh and Beckman 2004, Rittenhouse and Semlitsch 2006). Due to the limited vagility of both amphibians and reptiles as a result of their diminutive stature and physiological limitations (e.g., ties to water in amphibians), herpetofauna likely are more negatively affected by edges than other terrestrial vertebrate fauna. While a few studies have examined the effects of habitat edges on tropical herpetofauna (Toral et al. 
2002, Lehtinen et al. 2003), relative to the diversity found in the tropics, the effects of edges on the dispersal, community assembly, and interactions with edges are largely unknown.

Oophaga pumilio (Schmidt, 1857) is a small, terrestrial frog found throughout the lowland Caribbean rainforests of Nicaragua, Costa Rica, and Panama (Lötters et al. 2007). This species is of particular interest due to its radiation in color, pattern, and size seen in the Bocas del Toro archipelago of Panama (a trend that extends to surrounding mainland areas; Siddiqi et al. 2004). Here, this species has diverged into more than 20 phenotypically distinct morphs, with many being isolated on islands within the archipelago. Understandably, this phenotypic radiation has garnered interest among researchers to examine selective pressures among different populations that would lead to such a distinct divergence in phenotype (Summers et al. 1999, Maan and Cummings 2009, Hegna et al. 2012). As there are certainly even more subtle evolutionary changes occurring among these populations, it stands to reason that reactions to fragmentation and edge effects may also vary among populations.

I assessed the relationship of population density to habitat edges in nine different $O$. pumilio populations in the Bocas del Toro region. I tested the hypothesis that these frogs would avoid habitat edges as it may expose them to unfavorable environmental conditions or edge predators.

\section{Materials and Methods}

\section{Study Area}

The Bocas del Toro archipelago is a series of islands in the Caribbean on the western side of Panama. The frog populations used for this study were located on Cayo de Agua $\left(09.14^{\circ} \mathrm{N}, 82.04^{\circ}\right.$ $\mathrm{W})$, Isla Colon $\left(09.41^{\circ} \mathrm{N}, 82.31^{\circ} \mathrm{W}\right)$, San Cristobal $\left(09.27^{\circ} \mathrm{N}, 82.28^{\circ} \mathrm{W}\right)$, Loma Partida $\left(09.14^{\circ} \mathrm{N}, 82.17^{\circ} \mathrm{W}\right)$, Pastores $\left(09.23^{\circ} \mathrm{N}, 82.33^{\circ}\right.$ $\mathrm{W})$, Popa North $\left(09.21^{\circ} \mathrm{N}, 82.13^{\circ} \mathrm{W}\right)$, and
Solarte $\left(09.33^{\circ} \mathrm{N}, 82.21^{\circ} \mathrm{W}\right)$ islands with Almirante $\left(09.24^{\circ} \mathrm{N}, 82.36^{\circ} \mathrm{W}\right)$ and Uyama River $\left(09.10^{\circ} \mathrm{N}, 82.18^{\circ} \mathrm{W}\right)$ representing mainland areas. Notably, Isla Popa has two phenotypically distinct morphs at the northern and southern end of the island. For this study, I only focused on the northern population, hence the designation of Popa North.

\section{Population Density Estimates}

During the summer of 2009 (June-August), I assessed population density of samples sites along ten $100 \mathrm{~m}$ transects; only five transects were used for the Cayo de Agua population due to accessibility issues. I conducted transects between 0830 and 1530, during peak activity of this species, and averaged $41 \mathrm{~min}$ in duration. Transects followed established methods for quantifying avian edge effects (Manu et al. 2007), starting at the edge of a forest (typically where pasture meets forest) and continuing into the fragment $100 \mathrm{~m}$, ending in the forest interior. Though avian transects are typically 400-1530 $\mathrm{m}$, birds are far more mobile than small amphibians and $100 \mathrm{~m}$ transects were sufficient to reveal population patterns in sampled populations. Transects were at least $50 \mathrm{~m}$ from one another and ran parallel to one another and were not repeated. As frogs were encountered through visual encounters, I sexed (if possible) individuals, recorded location on the transect, and perpendicular distance from the transect.

Population density from transects can be estimated in a number of ways. The most conservative way of determining the width of the transect where animals are detectable is the halfnormal method (Burnham et al. 1980) which follows the following formula: $\mathrm{W}=\sqrt{(}\left(\sum \mathrm{D}^{2} / \mathrm{N}\right)$, where $\mathrm{D}$ is perpendicular distance from the transect line for each animal encountered and $\mathrm{N}$ is the total number of animals encountered on the transect. This, then, can be multiplied by the transect distance to get the area covered on the transect. I calculated population densities for each of the nine populations using the half- 
normal method for population density estimates from transects (Burnham et al. 1980). To determine if there were any differences in population density among populations, I conducted an analysis of variance (ANOVA) between half-normal density estimates for each population. If there was a difference $(\alpha=0.05)$, I used a post-hoc Tukey's test to determine where differences occurred.

To analyze the effects of edges on each population, I grouped frogs found on transects in meter intervals from $0 \mathrm{~m}$ to $100 \mathrm{~m}$ and summed each interval for all transects within a population to get the total number of frogs found at each interval (i.e., three frogs between $0-1 \mathrm{~m}$ for all transects of Population A, zero between 1-2 m for all transects of Population A, etc.). Using a simple linear regression for each population, I determined any relationship between distance from edge to the number of frogs found on transects. Also using a linear regression, I examined if there were any differences between males, females, or juveniles in terms of their distribution.

For two transects (one for Uyama and one for Popa North), I only detected one frog directly on the transect (i.e., $0 \mathrm{~m}$ off of the transect to either side). Consequently, I could not calculate a density estimate for those two transects as it would require dividing by zero, so I excluded those transects from the data analysis.

\section{Results}

\section{Population Density Estimates}

Populations were highly variable in the density of frogs with densities, on average, ranging from as low as $2.39 \pm 0.72 \mathrm{frogs} / 100 \mathrm{~m}^{2}$ in the Uyama population to as high as $13.52 \pm$ 3.14 frogs $/ 100 \mathrm{~m}^{2}$ in the Pastores population. Shapiro-Wilks tests revealed that both Pastores $(p=0.003)$ and Uyama $(p=0.007)$ were not normally distributed. Consequently, all data were $\log _{10}$ transformed to achieve a normal distribution. As would be expected with these large differences in populations, an ANOVA confirmed that there was a significant difference in population densities $\left(F_{8,74}=5.249, p=\right.$ 0.00002). I ran a post-hoc Tukey's HSD test to examine relationships between populations when there was a significant difference among densities. I found Pastores to be different from Almirante $(p=0.001)$, Isla Colon $(p=0.0006)$, Popa North $(p=0.001)$, and Uyama $(p=0.0002$; Figure 1).

\section{Edge Effects}

Populations showed variable reactions to proximity to edge. Only three of the nine populations (Isla Colon, Loma Partida, and Pastores) showed a significant positive relationship of density with increased distance from edge $\left(F_{1,99}=4.67, R^{2}=0.04, p=0.033 ; F_{1.99}=11.77\right.$, $R^{2}=0.11, p=0.0008$; and $F_{1,99}=7.2, R^{2}=0.07$, $p=0.009$, respectively; Figure 2). Only Loma Partida females $\left(F_{1,99}=9.51, R^{2}=0.09, p=\right.$ $0.003)$, Pastores females $\left(F_{1,99}=5.79, R^{2}=0.06\right.$, $p=0.018)$, and Pastores males $\left(F_{1.99}=10.14, R^{2}\right.$ $=0.09, p=0.002$ ) showed a significant positive relationship of population density with increased distance from forest edge.

\section{Discussion}

Edge effects have significant effects on species distribution throughout a landscape. Here, I demonstrate that populations of $O$. pumilio show differential responses to habitat edges. To my knowledge, this is the first study to show differential responses to habitat edges among populations. Most studies on edge effects extrapolate responses from a relatively small area to whole species (e.g., see Malcolm 1994, Flaspohler et al. 2001, Laurance 2004, Marsh and Beckman 2004). While this study also examines a small region in the range of $O$. pumilio, it specifically looks for population responses in a diverse species, which is not typically done for edge effect studies. Oophaga pumilio populations displaying differential 


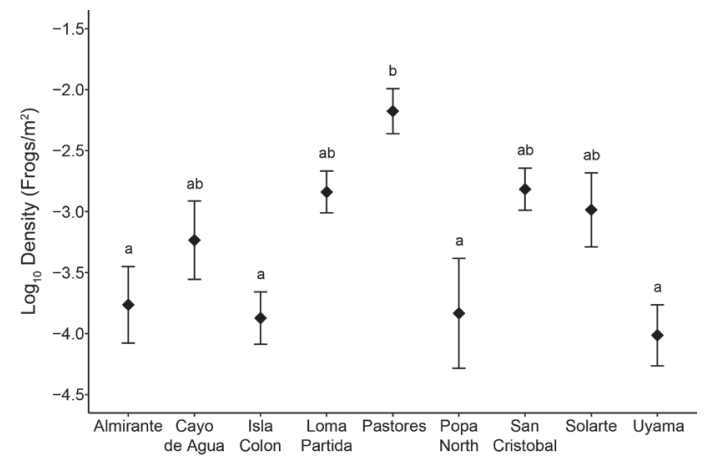

Figure 1. Log-transformed population densities of nine different populations of Oophaga pumilio. Points, with standard errors, represent mean density per $\mathrm{m}^{2}$ for each of the nine populations. Letters represent statistically significant $(\alpha=$ 0.05) differences among populations as a result from a Tukey's HSD test. Populations with the same letter are not statistically significant from one another.

response to edges highlights the need to approach research and conservation of this species at the population level, as these populations not only vary in color and pattern, but also vary in sensitivity to habitat edge (and possibly, perturbation). While $O$. pumilio can be found in a wide variety of habitats (both disturbed and undisturbed), evidence from this study suggests that despite this, some populations may show some sensitivity to habitat characteristics, such as edge.

Possible explanations for this pattern are varied. It is possible, for example, that the populations that display cryptic coloration (such as Isla Colon, Loma Partida, and Pastores), and likely reduced toxicity (Daly and Myers 1967, Maan and Cummings 2012), are more sensitive to forest edges as edges will increase their visibility to predators. However, this does not explain why other cryptic populations (i.e., Uyama and Popa North) do not show a similar pattern. The highly significant relationship of Loma Partida females to distance from forest edge while males show no such pattern is a

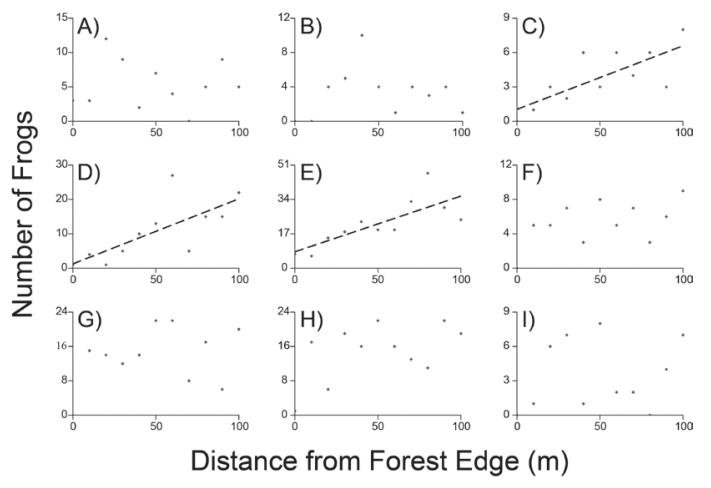

Figure 2. Simple linear regressions examining relationships to edges of the nine populations examined. Frogs were grouped by the meter. Dashed best-fit lines indicate a significant linear relationship ( $a=0.05$ ) between distance on the transect and frog abundance. Populations examined include (A) Almirante, (B) Cayo de Agua, (C) Isla Colon, (D) Loma Partida, (E) Pastores, (F) Popa North, (G) San Cristobal, (H) Solarte, and (I) Uyama.

curious result. As females must move up tree trunks to transport offspring to rearing sites, they may be easily seen by predators due to their dark blue-green coloration contrasting with lighter tree trunks. Future research should focus on microhabitat selection by the sexes to determine if niche differentiation exists among sexes.

Deforestation and habitat fragmentation occurs throughout human inhabited areas, but arguably, the impact to global biodiversity is much higher for tropical regions due to the high diversity found in these regions as well as the high amounts of endemism inherent to tropical areas. While some vertebrate groups' diversity is found in non-tropical regions (Stuart et al. 2004, Wiens 2007, Fritz and Rahbek 2012, Jenkins et al. 2013), the tropics harbor the highest diversity of amphibians and reptiles in the world. Consequently, any amount habitat fragmentation/ deforestation will likely have a greater impact on herpetofauna in the tropics as compared to temperate regions. Thus, understanding how 
herpetofauna respond to forest edges, both natural and human-induced, is of critical importance to predicting species' responses to disturbance.

Edge effects are an important phenomenon to consider when attempting to understand species distributions throughout an ecosystem. Most previous research has focused on a broad, species-wide explanation for individual distribution, when such may not be realistic in natural populations. This study examined a species that is phenotypically, morphologically, and behaviorally diverse despite very recent divergence (1,000-9,000 years; Anderson and Handley 2002). This diversity also extends to population response to edge. This is of particular importance because explaining species-wide distributions based on the responses of a single or few populations may result in erroneous conclusions. While most populations tested here did not show any relationship to forest edge, three populations did show a response. As these populations that did respond to forest edge vary phenotypically, morphologically, and behaviorally, no obvious pattern has been detected that could explain this variation. Future research should examine possible explanations for this population-level variation. This study highlights the importance of population-level investigations for understanding species-level phenomena.

\section{Acknowledgments}

I would like to thank Gerald Urquhart, Jim Harding, and Kelly Millenbah for their advice and direction for this project as well as their involvement in the editing process. I would also like to thank Brice Noonan for his valuable comments on the manuscript. I would like to thank Isaac Standish, Keith Erickson, and Craig Erickson for their invaluable help in collecting data over the course of the study. I would like to thank those at the Smithsonian Tropical Research Institution for their assistance in this project as well as the use of their facilities. This project was funded by the Graduate School of Michigan State University and was enacted under the
IACUC \#07/09-122-00 and Panamanian ANAM permit SE/A-67-09. Thank you to the two anonymous reviewers for their helpful suggestions for improving this manuscript.

\section{References}

Anderson, R. P. and C. O. Handley Jr. 2002. Dwarfism in insular sloths: biogeography, selection, and evolutionary rate. Evolution 56: 1045-1058.

Andren, H. and P. Angelstam. 1988. Elevated predation rates as an edge effect in habitat islands: experimental evidence. Ecology 69: 544-547.

Burnham, K. P., D. R. Anderson, and J. L. Laake. 1980. Estimation of density from line transect sampling of biological population. Wildlife Monographs 72: 3-202.

Collingham, Y. C. and B. Huntley. 2000. Impacts of habitat fragmentation and patch size upon migration rates. Ecological Applications 10: 131-144.

Crooks, K. R. 2002. Relative sensitivities of mammalian carnivores to habitat fragmentation. Conservation Biology 16: 488-502.

Daly, J. W. and C. W. Myers. 1967. Toxicity of Panamanian poison frogs (Dendrobates): some biological and chemical aspects. Science 156: 970-973.

Devictor, V., R. Julliard, and F. Jiguet. 2008. Distribution of specialist and generalist species along spatial gradients of habitat disturbance and fragmentation. Oikos 117: $507-514$.

Eizirik, E., J. H. Kim, M. Menotti-Raymond, P. G. Crawshaw Jr., S. J. O'Brien, and W. E. Johnson. 2001. Phylogeography, population history and conservation genetics of jaguars (Panthera onca, Mammalia, Felidae). Molecular Ecology 10: 65-79.

Fagan, W. F., R. S. Cantrell, and C. Cosner. 1999. How habitat edges change species interactions. American Naturalist 153: 165-182.

Flaspohler, D. J., S. A. Temple, and R. N. Rosenfield. 2001. Species-specific edge effects on nest success and breeding bird density in a forested landscape. Ecological Applications 11: 32-46.

Fritz, S. A. and C. Rahbek. 2012. Global patterns of amphibian phylogenetic diversity. Journal of Biogeography 39: 1373-1382.

Goosem, M. 2007. Fragmentation impacts caused by roads through rainforests. Current Science 93: 1587-1595. 
Hegna, R. H., R. A. Saporito, and M. A. Donnelly. 2012. Not all colors are equal: predation and color polytypism in the aposematic poison frog Oophaga pumilio. Evolutionary Ecology 27: 831-845.

Herkert, J. R. 1994. The effects of habitat fragmentation on midwestern grassland bird communities. Ecological Applications 4: 461-471.

Jenkins, C. N., S. L. Pimm, and L. N. Joppa. 2013. Global patterns of terrestrial vertebrate diversity and conservation. Proceedings of the National Academy of Sciences 110: e2602-e2610.

Kinnaird, M. F., E. W. Sanderson, T. G. O’Brien, H. T. Wibisono, and G. Woolmer. 2003. Deforestation trends in a tropical landscape and implications for endangered large mammals. Conservation Biology 17: 245-257.

Knutson, M. G., J. R. Sauer, D. A. Olsen, M. J. Mossman, L. M. Hemesath, and M. J. Lannoo. 1999. Effects of landscape composition and wetland fragmentation on frog and toad abundance and species richness in Iowa and Wisconsin, U.S.A. Conservation Biology 13: $1437-$ 1446.

Laurance, S. G. W. 2004. Responses of understory rain forest birds to road edges in Central Amazonia. Ecological Applications 14: 1344-1357.

Lehtinen, R. M., J. B. Ramanamanjato, and J. G. Raveloarison. 2003. Edge effects and extinction proneness in a herpetofauna from Madagascar. Biodiversity and Conservation 12: 1357-1370.

Lötters, S., K. H. Jungfer, F. W. Henkel, and W. Schmidt. 2007. Poison Frogs: Biology, Species, and Captive Husbandry. Chimaira. Serpent's Tale Natural History Book Distributors. 668 pp.

Maan, M. E. and M. E. Cummings. 2009. Sexual dimorphism and directional sexual selection on aposematic signals in a poison frog. Proceedings of the National Academy of Sciences of the United States of America 106: 19072 19077.

Maan, M. E. and M. E. Cummings. 2012. Poison frog colors are honest signals of toxicity, particularly for bird predators. American Naturalist 179: e1-e14.
Malcolm, J. R. 1994. Edge effects in central Amazonian forest fragments. Ecology 75: 2438-2445.

Manu, S., W. Peach, and W. Cresswell. 2007. The effects of edge, fragment size and degree of isolation on avian species richness in highly fragmented forest in West Africa. Ibis 149: 287-297.

Marsh, D. M. and N. G. Beckman. 2004. Effects of forest roads on the abundance and activity of terrestrial salamanders. Ecological Applications 14: 1882-1891.

Ries, L. and T. D. Sisk. 2010. What is an edge species? The implications of sensitivity to habitat edges. Oikos 119: 1636-1642.

Rittenhouse, T. A. G. and R. D. Semlitsch. 2006. Grasslands as movement barriers for a forest-associated salamander: migration behavior of adult and juvenile salamanders at a distinct habitat edge. Biological Conservation 131: 14-22.

Siddiqi, A., T. W. Cronin, E. R. Loew, M. Vorobyev, and K. Summers. 2004. Interspecific and intraspecific views of color signals in the strawberry poison frog Dendrobates pumilio. Journal of Experimental Biology 207: 24712485.

Stuart, S. N., J. S. Chanson, N. A. Cox, B. E. Young, A. S. L. Rodrigues, D. L. Fischman, and R. W. Waller. 2004. Status and trends of amphibian declines and extinctions worldwide. Science 306: 1783-1786.

Summers, K., R. Symula, M. E. Clough, and T. W. Cronin. 1999. Visual mate choice in poison frogs. Proceedings of the Royal Society of London, Series B Biological Sciences 266: 2141-2145.

Toral, E., P. Feinsinger, and M. L. Crump. 2002. Frogs and a cloud-forest edge in Ecuador. Conservation Biology 16: $735-744$.

Wiens, J. J. 2007. Global patterns of diversification and species richness in amphibians. American Naturalist 170: S86-106. 